\title{
Effect of Dietary Protein Level during Estrus Cycle: Nutrient Digestibility, Quality of Embryo and Pregnancy Rate by Embryo Transfer in Thai Crossbred Goats during Hot Season
}

\section{Juggrid JUGSUMRIT ${ }^{1}$, Chalermpon YUANGKLANG ${ }^{2, *}$, Kraisit VASUPEN ${ }^{2}$, Benya SAENMAHAYAK ${ }^{2}$ and Chantira WONGNEN ${ }^{3}$}

\author{
${ }^{I}$ Nakhonratchasima A.I and Biotechnology Research Center, Nakhon Ratchasima 30130, Thailand \\ ${ }^{2}$ Rajamagala University of Technology Isan, Nakhon Ratchasima Campus, \\ Nakhon Ratchasima 30000, Thailand \\ ${ }^{3}$ School of Agricultural Technology, Walailak University, Nakhon Si Thammarat 80160, Thailand
}

("Corresponding Author's e-mail: chayua@hotmail.com)

Received: 5 June 2020, Revised: 11 November 2020, Accepted: 22 December 2020

\begin{abstract}
Tis study aimed to evaluate the embryo quality and embryo transfer rate of Thai crossbred goats fed different levels of protein in total mixed rations (TMR) during the hot season. Twenty-four non- pregnant Thai crossbred goats with an average body weight of $26 \pm 5.9 \mathrm{~kg}$ were assigned with a random complete block design (RCBD). Dietary treatments contained 8, 13, and $18 \%$ crude protein (CP) in TMR. The feeding trial lasted for 42 days. Does (female goat) were scheduled to determine embryo quality by surgical laparotomy and flushing. At the end of the feeding trial, the digestion trial was conducted by the total collection method for a 5-day period. The results showed that the average total feed intake and feed conversion ratio did not differ among all treatments $(p>0.05)$, however, digestible protein intake had increased from $70.39,79.77$ to $89.11 \mathrm{~g} / \mathrm{d}$ in 8, 13, and $18 \% \mathrm{CP}$ group, respectively. Increasing $\mathrm{CP}$ levels in TMR resulted in linearly increased goat final body weight $(30.25,28.75$, and $32.00 \mathrm{~kg})$, weight gain $(3.00,4.00$, and $4.25 \mathrm{~kg})$, and average daily gain (ADG) $(87.84,114.87$ and $121.63 \mathrm{~g} / \mathrm{d})$. Embryo quality $(1,1$, and 3.5 morular follicle state) and pregnancy of embryo transfer rate $(25,25$, and $50 \%)$ of the animal received $\mathrm{CP}$ level at 8 and $13 \%$ less than that $18 \%$. These results indicated that dietary protein level during program superovulation regimen affected the good quality of an embryo and the pregnancy rate in an embryo transfer in Thai crossbred goats.
\end{abstract}

Keywords: Embryo, Goats, Nutrition, Pregnancy rate, Reproduction, Superovulation

\section{Introduction}

Goat farming is practiced worldwide, with goat products having a favorable image [1,2]. The number of goats has increased globally, even in countries with high and intermediate incomes, despite major changes in agriculture due to industrial mergers, globalization, and technological advances in developed countries [3,4]. There are 30 million heads of cashmere goats around the world [5]. Goat production is one of the key elements contributing to the economy of farmers living in the arid and semiarid regions. [6,7]. The most important goat breeding continents are Asia and Africa [8]. In developing countries, $96 \%$ of the milk and meat producing goat populations are found and $4 \%$ are found in developed countries [9]. Increasing meat production using scientific, accurate, and precise selective programs are one of the most important goals for the genetic improvement of goats [10]. This can be done by identifying the genetic reproductive and productive traits of animals [11-13]. Moreover, ruminant production is primarily based on locally available feed resources. Goat production is one of the most 
http://wjst.wu.ac.th

popular ruminant animals due to its advantages in high reproductive performance and small land for rearing. Goats are fed based on both natural forages and agricultural by-products. The does are small ruminants which have a high potential to utilize low-quality roughage and can adjust well and consume natural feedstuffs, most goats are raised in public fields alongside roads by smallholder farmers with an average number of 26.3 head per household [14]. Thailand is located in the tropical region where high temperature and high moisture contents can be met. Heat stress is well known to influence animal production and reproduction. The heat stress demonstrates less the pregnancy rate in goats and has been thought to be associated with early embryonic death. In vitro cultures have been more used for the evaluation of effects of heat stress on oocytes, fertilization, preimplantation, and embryonic development [15]. Nutrition is one of the most important and controllable management factors influencing reproductions [16]. The effect of dietary protein on reproduction is complex, lacking protein intake reduced reproductive performance [17]. More recently it has been found that reproductive performance may be impaired if a protein is fed in amounts that greatly exceed the animal's requirements. Overfeeding of either as protein or urea has been associated with decreased pregnancy rates in female dairy and beef cattle $[18,19]$. It appears that exposure to high levels of ammonia or urea may impair the maturation of oocyte and subsequent fertilization or maturation of developing embryos. However, supplying adequate energy for the excretion of excess ammonia or urea may prevent decreases in fertility in dry cows or heifers [20]. Besides, not all studies have observed negative effects of elevated blood urea nitrogen (BUN) concentrations on embryo quality or pregnancy rate [21]. Overfeeding protein during the breeding season and early gestation, particularly if the ruminants receives an inadequate supply of energy may be associated with decreased fertility [22]. This decrease fertility may result from decreased uterine $\mathrm{pH}$ during the luteal phase of the estrous cycle in cattle fed high levels of degradable protein. The interaction between nutrition and reproduction has long been known to have important implications for reproductive performance [19].

The objectives of the present study were to investigate the effect of feeding diets that contained different levels of crude protein (CP) during the estrus cycle on the quality embryos in program superovulation of Thai crossbred goats and productive performance.

\section{Materials and methods}

\section{Animal ethics}

The experiment was performed under the ethical regulations of Rajmangala University of Technology Isan. This study was conducted at the Rajamangala University of Technology Isan, Nakhon Ratchasima, Thailand.

\section{Animal management and experimental design}

Twenty-four Thai crossbred goats with non-pregnant and pass $2^{\text {nd }}$ cycling of estrus, approximately 2 - 4 years of age, with average body weight $(\mathrm{BW})$ of $26 \pm 5.9 \mathrm{~kg}$. All goats were kept in individual cages of $1 \times 1.5 \mathrm{~m}^{2}$ and received the vaccine against foot and mouth disease (FMD), brucellosis test, and antiinternal and external worm were injected to ensure the vitamin sufficiency and a worm-free condition, respectively, before the experiment started. The animals were randomly assigned according to Randomized Complete Block Design (RCBD) with 4 blocks (initial body weight and age). The feeding trial lasted for 42 days and 15 days of an adjustment period.

\section{Experimental feed and feeding}

Dietary treatments were the different levels of CP content in TMR, which were 8,13 , and $18 \% \mathrm{CP}$, Feed ingredients of experimental are presented in Table 1. Goats were ad libitum fed twice daily at 08.00 and 16.00 and clean water was freely accessed. Feed refusals were measured and sampled daily at 07.30 on the next day.

At the end of the experimental period, all animals were used for a digestibility trial that was conducted using the total collection method for a 5-day period. Feeds, feed refusals, and feces were weighed and then $10 \%$ of feed refusals and feces were sub-sampled each day. Composites of feeds, feed 
http://wjst.wu.ac.th

refusals, and feces were sub-sampled approximately $500 \mathrm{~g}$ from each goat. Samples were dried at $65^{\circ} \mathrm{C}$ for $24 \mathrm{~h}$ and ground to pass a $1 \mathrm{~mm}$ screen using Wiley mill. The samples were stored at $-21{ }^{\circ} \mathrm{C}$ pending further chemical analysis. The proximate chemical composition of feeds, feed refusals, and feces samples contents of feeds were analyzed by a method described by AOAC [23].

The does were initially weighed at the beginning of the experiment and weighed monthly throughout the experimental period. At the end of the experimental period, the average weight of the individual animal was also recorded.

Table 1 Composition of concentrate in total mixed rations used in the experiment.

\begin{tabular}{lccc}
\hline \multirow{2}{*}{ Ingredients } & \multicolumn{3}{c}{ Protein level (\%) } \\
\cline { 2 - 4 } & $\mathbf{8}$ & $\mathbf{1 3}$ & $\mathbf{1 8}$ \\
\hline Corn silage & 40 & 40 & 40 \\
Soybean meal & 1.20 & 8.40 & 15.00 \\
Cassava chip & 33.60 & 28.20 & 20.40 \\
Corn meal & 7.20 & 6.00 & 6.00 \\
Rice bran & 7.20 & 6.00 & 6.00 \\
Dried Brewers grains & 7.20 & 8.70 & 9.00 \\
Urea & 0.60 & 0.90 & 1.80 \\
Molasses & 2.40 & 1.20 & 1.20 \\
Salt & 0.18 & 0.18 & 0.18 \\
Sulfur & 0.30 & 0.30 & 0.30 \\
Premix & 0.12 & 0.12 & 0.12 \\
\hline Total & 100 & 100 & 100 \\
\hline Metabolizable energy (Mcal) & 2.62 & 2.65 & 2.64 \\
\hline
\end{tabular}

\section{Program of superovulation and synchronization}

After the feeding trial experiment, goats were induced into superovulation and synchronized estrus using 1 protocol for each of the 3 treatments. Twelve goats to select the method applied for superovulation (donor) and twelve goats to select the method applied for synchronization (recipient). In the donor group, the controlled internal drug release device, CIDR-G (EAZI-Breed TM CIDR $\AA$, Pfizer, Auckland, New Zealand) containing $0.3 \mathrm{~g}$ progesterone was used as the intravaginal progesterone delivery system. Day 0 was designated as the day of CIDR-G insertion and concurrently $125 \mu \mathrm{g}$ cloprostenol (Estroplan $^{\circledR}$, Parnell Laboratories (AUST) Pty. Ltd., Alexandria, NSW, Australia) was administered intramuscularly, inserted with CIDR-G for 12 days, then injected intramuscularly with FSH 120 IU twice daily $(6,5$ and $4 \mathrm{mg}$ per injection on day 9,10 and 11 , respectively), injected prostaglandin $\mathrm{F}_{2 \alpha}$ (PG) $125 \mathrm{ug}$, GnRH $150 \mathrm{IU}$, removed CIDR-G on d 12 and inseminated with frozen semen TAI at 48, 56 and $72 \mathrm{~h}$ after CIDR-G removal. All treated animals were exposed to vasectomized bucks 1 day before CIDR-G removal to stimulate estrus. Laparotomy surgery after TAI on $\mathrm{d} 7$. In the recipient group, the does were administered with control intravaginal drug release (CIDR-G) for 12 days, injected PG $125 \mathrm{ug}$, GnRH 150 IU, and removed CIDR-G on d 12. Laparotomy surgery was performed after estrus on d 7.

\section{Data collection and analysis}

Blood samples were collected on the morning of estrus via jugular venipuncture into an EDTA solution, then immediately centrifuged at $1,500 \times \mathrm{g}$ for $15 \mathrm{~min}$. Blood plasma samples were harvested and frozen stored at $-20{ }^{\circ} \mathrm{C}$ until assayed of blood urea nitrogen (BUN). Laparotomy surgery was conducted after TAI on d 9. Goats were injected with $0.075 \mathrm{mg}$ xylazine (Rompun ${ }^{\circledR}$; L.B.S. Laboratory, Thailand) and $100 \mathrm{mg}$ ketamine hydrochloride (Ketaset ${ }^{\circledR}$; Wyeth Animal Health, Canada), and the embryo was collected and evaluated. After laparotomy was performed, the number of corpus luteam (CL) on each 
http://wjst.wu.ac.th

ovary was recorded. Each embryo was then flushing and evaluated based on morphology and categorized as good or poor quality as previously described by [24]. After the end of the embryo transfer, all animals have used ultrasound scanning at 45 days recheck pregnancy rate in goats.

\section{Statistical analysis}

All obtained data were subjected to the Analysis of Variance (ANOVA) according to an RCBD design. Means were statistically compared using LSD and orthogonal polynomial. The statistical model was:

$Y_{i j}=\mu+\beta_{i}+\boldsymbol{\tau}_{j}+\varepsilon_{i j}$

Where $Y_{i j}$ was observed variable, $\mu$ was the overall mean, $\beta_{i}$ was the random effect of the $i^{\text {th }}$ block, $\tau_{\mathrm{i}}$ was the fixed effect of the $\mathrm{j}^{\text {th }}$ treatment $(\mathrm{i}=1,2,3)$ and $\varepsilon_{\mathrm{ijk}}$ was the residual error.

\section{Results and discussion}

\section{Chemical composition of experimental total mixed rations}

All experimental diets were provided a similar amount of DM, OM, EE, CP, and Ash to all treatments (Table 2). As expected, crude protein contents of dietary treatments varied with treatment. In this study, the diet component was placed to the level at 60:40 of concentrate: forage ratio following the reports of [25], who found that this ratio significantly improved feed utilization by goats. Intake of dietary of protein level affected growth performance, in term of final weight in goats. As reported by [26], who studied the effect of dietary protein level in TMR at 14,16,18, and $20 \% \mathrm{CP}$ on growth performance of Korean black goat. The result found that growth performance in Korean black goats was improved by 18 $\% \mathrm{CP}$.

Table 2 Chemical composition of dietary protein levels.

\begin{tabular}{lccc}
\hline \multirow{2}{*}{ Chemical composition } & \multicolumn{3}{c}{ Protein levels (\%) } \\
\cline { 2 - 4 } & $\mathbf{8}$ & $\mathbf{1 3}$ & $\mathbf{1 8}$ \\
\hline DM & 50.48 & 51.29 & 50.93 \\
OM & & -1.93 & 93.55 \\
CP & 94.05 & 93.30 & 18.29 \\
EE & 8.81 & 13.97 & 3.28 \\
NDF & 3.40 & 3.40 & 45.28 \\
ADF & 37.03 & 41.21 & 27.24 \\
Ash & 27.10 & 26.91 & 6.45 \\
\hline
\end{tabular}

\section{Effect of dietary protein level on feed intake and growth characteristics of goats}

The effects of CP level in TMR on body weight gain, growth performance characteristics, and dry matter intake of Thai crossbred goats are presented in Table 3. The average daily gain (ADG) of all treatment was varied from 87.84 to $121.63 \mathrm{~g}$ during the experimental period. Dry matter intake (DM) of 13 and $18 \% \mathrm{CP}(4.00$ and $4.25 \% \mathrm{BW})$ were higher than $8 \% \mathrm{CP}$ group $(3.00 \% \mathrm{BW})$ but did not significantly differ $(p>0.05)$ by dietary protein levels in TMR. The result of this study was consistent to the report of [27], who found that there was no effect of different levels of CP in diets on DMI of either Boer-Spanish crossbred or Spanish kids. This was, however, in contrast to the report of [28], who found that increasing dietary levels of CP in diet had increased levels of DMI. It is possible that the difference in feed ingredients and animal breed resulted in this dissimilarity. As expected, increased levels of dietary 
http://wjst.wu.ac.th

protein level in TMR resulted in significantly increased CPI and digestible crude protein intake (DCPI) of the animals. Increasing $\mathrm{CP}$ levels in $\operatorname{TMR}(8,13$, and $18 \%)$ led to a linearly increased goat's final body weight and ADG. Growth performances of Thai indigenous goats from this study are consistent with the performance of goats reported by [29], who reported that Saanen kids fed the minimum dietary CP levels had the lowest ADG and the ADG significantly increased when the kids fed diets with higher levels of CP diets. Furthermore, [30] reported that both Thai indigenous and crossbred kids received more CP resulted in higher growth rates. Similarly, [31] found that the significant responses of final body weight, weight gain, and ADG of Thai indigenous x Anglo-Nubian crossbred to increasing levels of dietary CP linearly. This finding indicated that Thai indigenous goat responded well to the amount of CP intake.

Table 3 Effect of dietary protein levels on intake and growth characteristics of goats.

\begin{tabular}{|c|c|c|c|c|c|c|}
\hline \multirow{2}{*}{ Item } & \multicolumn{3}{|c|}{ Protein Levels (\%) } & \multirow{2}{*}{ SEM } & \multicolumn{2}{|c|}{ Contrast } \\
\hline & 8 & 13 & 18 & & Linear & Quadratic \\
\hline Initial weight $(\mathrm{Kg})$ & 27.00 & 24.50 & 27.00 & & & \\
\hline Final weight (Kg) & 30.25 & 28.75 & 32.00 & & & \\
\hline $\mathrm{ADG}, \mathrm{g} / \mathrm{d}$ & $87.84^{\mathrm{c}}$ & $114.87^{\mathrm{b}}$ & $121.63^{\mathrm{a}}$ & 2.12 & $*$ & $*$ \\
\hline $\mathrm{FCR}$ & 10.94 & 10.31 & 10.92 & 0.67 & ns & ns \\
\hline $\begin{array}{l}\text { Feed intake, } \\
\text { g DM/d }\end{array}$ & 944 & 1,165 & 1,309 & 137.38 & ns & ns \\
\hline$\% \mathrm{BW}$ & 3.00 & 4.00 & 4.25 & 0.46 & ns & ns \\
\hline $\mathrm{g} / \mathrm{kgBW}^{0.75}$ & 72.76 & 95.25 & 94.88 & 9.34 & ns & ns \\
\hline
\end{tabular}

${ }^{\mathrm{a}, \mathrm{b}, \mathrm{c}}$ Mean with different superscript within the same row are statistically different $(p<0.05)$, SEM = standard error of the means, $\mathrm{ns}=$ non-significant $(p>0.05), *=p<0.05$

\section{Nutrients digestibility}

Nutrients digestibility of dietary treatments in Thai crossbred goats is shown in Table 4. DM, OM, and ADF digestibility of $18 \% \mathrm{CP}(78.07,80.45$ and $54.19 \%$, respectively) were highest, however, those were not significantly different $(p>0.05)$ goats from $8 \%(72.02,73.51$ and $45.37 \%$, respectively) and 13 \% CP group (71.33, 73.80 and 41.55\%, respectively). Moreover, CP and NDF digestibility was significantly affected $(p<0.05)$ by dietary protein levels, with quadratically increased $(p<0.01)$ according to increase inclusion levels of CP in TMR. Protein and NDF utilization levels increased due to improvement in the efficiency of microbial capture of the available $\mathrm{N}$ supply. Our finding was consistent with the report of [29]. These authors found that goats fed with diet ad libitum $\left(54.2 \mathrm{~g} / \mathrm{BW}^{0.75} / \mathrm{d}, \mathrm{DMI}\right)$ had CP digestibility of $80.8 \%$, and the CP digestibility was significantly decreased when the goats were fed with a lower amount of feed or CP. This study was consistent with the report of [28], who reported that Saanen kids with diet CP levels ad libitum had CP digestibility of $80.8 \%$ and the CP digestibility was significantly decreased when the goats were fed with a lower amount of feed or CP. NDF digestibility was improved $(p<0.05)$ in goats fed $18 \% \mathrm{CP}$ compared with goats fed 8.0 and $13 \% \mathrm{CP}$. It implied that more protein available for microbial growth in the rumen, enhancing the degradation of nutrients including fiber content. The data from [32] reported that microbial growth is strongly positively related to voluntary feed intake, increasing the level of feed intake increased the digestible of organic matter in the rumen and supplied more nutrients for microbial crude protein synthesis (MCP). The literature states that the most microbial population in the rumen are fibrolytic and have the high proteolytic capacity [33], then improved CP and NDF digestibility in the high protein diet group. 
http://wjst.wu.ac.th

Table 4 Nutrient digestibility (\%) of different levels of crude protein in total mixed rations.

\begin{tabular}{|c|c|c|c|c|c|c|}
\hline \multirow{2}{*}{ Items } & \multicolumn{3}{|c|}{ Protein Level (\%) } & \multirow[t]{2}{*}{ SEM } & \multicolumn{2}{|c|}{ Contrast } \\
\hline & 8 & 13 & 18 & & Linear & Quadratic \\
\hline Dry matter & 72.02 & 71.33 & 78.07 & 2.61 & ns & ns \\
\hline Organic matter & 73.51 & 73.80 & 80.45 & 2.55 & ns & $\mathrm{ns}$ \\
\hline Crude protein & $70.39^{c}$ & $79.77^{\mathrm{b}}$ & $89.11^{\mathrm{a}}$ & 2.37 & $* *$ & $* *$ \\
\hline Ether extract & 83.70 & 79.35 & 85.11 & 2.57 & ns & ns \\
\hline NDF & $51.08^{b}$ & $48.89^{b}$ & $61.60^{\mathrm{a}}$ & 1.93 & ns & $* *$ \\
\hline $\mathrm{ADF}$ & 45.37 & 41.55 & 54.19 & 4.43 & ns & $\mathrm{ns}$ \\
\hline
\end{tabular}

${ }^{\mathrm{a}, \mathrm{b}, \mathrm{c}}$ Mean with different superscript within the same row are significantly differed $(p<0.05)$, SEM = standard error of the means, $\mathrm{ns}=$ non-significant $(p>0.05), * *=p<0.01$

$\mathrm{NDF}=$ neutral detergent fiber; $\mathrm{ADF}=$ acid detergent fiber

Table 5 Effect of dietary protein level on $\mathrm{pH}$, ammonia nitrogen $\left(\mathrm{NH}_{3}-\mathrm{N}\right)$, and blood urea nitrogen (BUN) concentration.

\begin{tabular}{|c|c|c|c|c|c|c|}
\hline \multirow{2}{*}{ Items } & \multicolumn{3}{|c|}{ Protein level (\%) } & \multirow{2}{*}{ SEM } & \multicolumn{2}{|c|}{ Contrast } \\
\hline & 8 & 13 & 18 & & Linear & Quadratic \\
\hline \multicolumn{7}{|l|}{$\mathrm{pH}$} \\
\hline $0 \mathrm{~h}$ & 7.16 & 6.96 & 7.00 & 0.10 & ns & ns \\
\hline $2 \mathrm{~h}$ & 6.79 & 6.46 & 6.61 & 0.13 & ns & ns \\
\hline $4 \mathrm{~h}$ & 6.79 & 6.57 & 6.81 & 0.14 & $\mathrm{~ns}$ & ns \\
\hline Mean & 6.91 & 6.66 & 6.81 & 0.11 & $\mathrm{~ns}$ & ns \\
\hline \multicolumn{7}{|c|}{$\mathrm{NH}_{3} \mathrm{~N}(\mathrm{mg} \%)$} \\
\hline $0 \mathrm{~h}$ & $6.58^{c}$ & $7.58^{\mathrm{b}}$ & $9.18^{\mathrm{a}}$ & 0.15 & $*$ & $*$ \\
\hline $2 \mathrm{~h}$ & 9.77 & 12.57 & 14.68 & 1.27 & ns & ns \\
\hline $4 \mathrm{~h}$ & 8.12 & 9.15 & 8.51 & 0.39 & ns & ns \\
\hline Mean & $8.16^{b}$ & $9.77^{\mathrm{ab}}$ & $10.79^{\mathrm{a}}$ & 0.39 & $*$ & $*$ \\
\hline \multicolumn{7}{|l|}{ BUN (mg\%) } \\
\hline $0 \mathrm{~h}$ & $4.00^{c}$ & $9.50^{\mathrm{b}}$ & $15.50^{\mathrm{a}}$ & 1.07 & $* *$ & $* *$ \\
\hline $2 \mathrm{~h}$ & $6.25^{b}$ & $13.50^{\mathrm{a}}$ & $19.25^{\mathrm{a}}$ & 1.82 & $* *$ & $* *$ \\
\hline $4 \mathrm{~h}$ & $5.25^{\mathrm{c}}$ & $12.50^{\mathrm{b}}$ & $19.75^{\mathrm{a}}$ & 1.67 & $* *$ & $* *$ \\
\hline Mean & $5.17^{\mathrm{c}}$ & $11.83^{\mathrm{b}}$ & $18.16^{\mathrm{a}}$ & 1.48 & $* *$ & $* *$ \\
\hline
\end{tabular}

a,b,c Mean with different superscript within the same row are statistically different $(p<0.05)$, SEM = standard error of the means, $\mathrm{ns}=$ non-significant $(p>0.05), *=p<0.05, * *=p<0.01$

\section{Ruminal pH, $\mathrm{NH}_{3}-\mathrm{N}$, and BUN}

The result of blood metabolization was shown in Table 5, $\mathrm{pH}$ in rumen fermentation was not significantly different between the treatments $(6.91,6.66$, and 6.81 , respectively). Rumen $\mathrm{pH}$ values were within the physiological range of $6.6-7.1$ which had no negative effect on bacterial growth. As same as with BUN, BUN concentrations in this study were in the normal level according to [1], the normal level of BUN concentration was $10-20 \mathrm{mg} / \mathrm{dl}$. However, $\mathrm{NH}_{3}-\mathrm{N}$ in rumen fermentation metabolites $(8.16$, 9.77, and 10.79, respectively, $p<0.05)$ and $\operatorname{BUN}(5.17,11.83$ and $18.16 \mathrm{mg} \%$, respectively, $p<0.01)$ had increased gradually after feeding on 0,2 , and $4 \mathrm{~h}$, and quadratically increased with increasing levels of $\mathrm{CP}$ in the diets. The higher level of $\mathrm{NH}_{3}-\mathrm{N}$ and $\mathrm{BUN}$ in the high protein diet group would relate to protein degradation in the rumen which is the main reason for the efficient protein utilization in ruminants. Ammonia-nitrogen is the major products of protein degradation in the rumen that are crucial 
http://wjst.wu.ac.th

for microbial growth and minor rates of ruminal degradation improved efficiency of MCP synthesis due to the better holding of releasing $\mathrm{N}$ by rumen microbes [32]. However, it is proposed that the capture of rumen degradable protein is not completed, when the ammonia amount is large due to the extensive degradation of the proteins, the surplus of ammonia is absorbed through the lining of the tract. Later, it is turned into urea in the liver, to reduce its toxicity to the animal, and lead high amount of BUN. The BUN may be recycled to the rumen as non-protein nitrogen [33] and leading to a higher level of $\mathrm{NH}_{3}-\mathrm{N}$ prior feeding of high CP group $(9.18 \mathrm{mg} \%)$ than others $(6.58$ and $7.58 \mathrm{mg} \%$, respectively).

Effect of dietary protein level on pregnancy rate in embryo transfer and quality of an embryo

Laparotomy of the donor was performed at $\mathrm{d} 7$ after AI, then the number of embryos and CL were recorded. The mean recovery of an embryo in donors fed different protein levels of 8,13 , and $18 \%$ were 10,5 , and 10.25 , respectively $(p>0.05)$. The embryo quality was evaluated by using state of embryo in goats receiving protein level at $18 \%$ and was significantly higher $(p<0.05)$ than the goats fed protein level at $8 \%$ and $13 \%$ as shown in Table 6. In recipients, the result of number $(6,5$, and 6 , respectively) and the pregnancy rate in embryo transfer in fed high levels of protein $(50 \%)$ were higher than the lower groups ( 25 and $25 \%$, respectively). In females of small ruminant species, nutritional supplementation stimulates envelopment of the small follicle population [31], growth rate and size of the ovulatory follicle [34], ovulation rate [35], and litter size [36]. In this research, results belonging to CP level and utilization in diets, in ruminants, low protein diets resulted in low BUN, whereas high BUN was associated with high protein diets or excessive protein breakdown. Inadequate protein intake showed a lower BUN concentration and negative effect on conception rate, fetal reabsorptions, premature parturition, and weak offspring [37], however, exceeds BUN concentrations has been negatively associated with reduced conception rates and increased early embryonic death. The effects of urea on embryo quality are likely to be due to alterations in the oviduct environment or deleterious changes in the follicle, rather than changes in the uterine environment [38,39]. Depending upon protein quality and composition, serum concentrations of progesterone may be lowered, the uterine environment altered, and fertility decreased [40].

Table 6 Effect of dietary protein levels on pregnancy rate in embryo transfer and quality of an embryo.

\begin{tabular}{lccccccc}
\hline \multirow{2}{*}{ Item } & \multicolumn{3}{c}{ Protein level (\%) } & \multirow{2}{*}{ SEM } & \multicolumn{3}{c}{ Contrast } \\
\cline { 2 - 4 } & $\mathbf{8}$ & $\mathbf{1 3}$ & $\mathbf{1 8}$ & & & Linear & Quadratic \\
\hline Donor (n) & 4 & 4 & 4 & & & $\mathrm{~ns}$ \\
Number of CL (n) & 10.00 & 5.00 & 10.25 & 1.80 & $\mathrm{~ns}$ & $\mathrm{~ns}$ \\
Quality of embryos (donor) & & & & & & $\mathrm{ns}$ \\
$\quad$ Unfertilized Ovum (UFO, n) & 7.00 & 2.75 & 2.50 & 1.93 & $\mathrm{~ns}$ & $\mathrm{~ns}$ \\
$\quad$ Degenerated (n) & 1.25 & 0.75 & 1.25 & 0.47 & $\mathrm{~ns}$ & $\mathrm{~ns}$ & \\
$\quad$ Morula & $1.00^{\mathrm{b}}$ & $1.00^{\mathrm{b}}$ & $3.50^{\mathrm{a}}$ & 0.55 & $\mathrm{~ns}$ & \\
$\quad$ Blastocyst & 0.75 & 0.50 & 3.00 & 0.84 & & & \\
Recipient (n) & 4 & 4 & 4 & & & & \\
Number of total CL (n) & 6 & 5 & 6 & & & & \\
Pregnancy recipient (n) & 1 & 1 & 2 & & & & \\
\hline
\end{tabular}

${ }^{\mathrm{a}, \mathrm{b}}$ Mean with different superscript within the same row are statistically different $(p<0.05)$, SEM = standard error of the means, $\mathrm{ns}=$ non-significant $(p>0.05), *=p<0.05$ 
http://wjst.wu.ac.th

\section{Conclusions}

Average total feed intake was not different, while ADG was significantly different fed level protein group. However, the fed level $18 \%$ protein-induced compensatory growth on embryo quality, follicular development greater than 8 and $13 \%$ group. Thus, the results indicated that reproductive management in pubertal and pre-gestation periods using the different fed level protein regimen affected fertility improvement in Thai-native crossbreed goats.

\section{Acknowledgments}

The authors would like to thank Nakhon Ratchasima A.I. and Biotechnology Research Center and Nakhon Ratchasima E.T center, and staff members of HHU Phakchong Nakhon Ratchasima. We would also like to express our sincere thanks to the Rajamagala University of Technology Isan for facilities support.

\section{References}

[1] FG Gooki, M Mohammadabadi, MA Fozi and M Soflaei. Association of biometric traits with growth hormone gene diversity in Raini Cashmere Goats. Walailak J. Sci. Tech. 2019; 16, 499-508.

[2] M Khorshidi, MR Mohammadabadi, AK Esmailizadeh, A Barazandeh and OI Babenko. Comparison of artificial neural network and regression models for prediction of body weight in Raini Cashmere goat. Iran. J. Appl. Anim. Sci. 2019; 9, 453-61.

[3] FG Gooki, MR Mohammadabadi and MA Fozi. Polymorphism of the growth hormone gene and its effect on production and reproduction traits in goat. Iran. J. Appl. Anim. Sci. 2018; 8, 653-9.

[4] S Shamsalddini, MR Mohammadabadi and AK Esmailizadeh. Polymorphism of the Prolactin gene and its effect on fiber traits in goat. Russ. J. Genet. 2016; 52, 405-8.

[5] A Baghizadeh, M Bahaaddini, MR Mohamadabadi and N Askari. Allelic variations in exon 2 of Caprine MHC class II DRB3 gene in Raeini Cashmere goat. Am. J. Agri. Environ. Sci. 2009; 6, 4549.

[6] A Barazandeh, SM Moghbeli, M Vatankhah and MR Mohammadabadi. Estimating non-genetic and genetic parameters of pre-weaning growth traits in Raini Cashmere goat. Trop. Anim. Health Prod. 2012; 44, 811-7.

[7] M Moghadaszadeh, MR Mohammadabadi and AK Esmailizadeh. Association of exon 2 of BMP15 gene with the litter size in the Raini Cashmere goat. Genetics in the $3^{\text {rd }}$ Millenn 2015; 13, 4062-7.

[8] MR Mohammadabadi and F Tohidinejad. Charachteristics determination of Rheb gene and protein in Raini Cashmere goat. Iran. J. Appl. Anim. Sci. 2017; 7, 289-95.

[9] AVN Esmaeili, AE Koshkooieh, AM Aytolahi, MR Mohammadabadi, OI Babenko, M Bushtruk, S Tkachenko, R Stavetska and N Klopenko. Comparison of genetic diversity of leptin gene between wild goat and domestic goat breeds in Iran. Malays. Appl. Biol. 2019; 48, 85-93.

[10] SM Moghbeli, A Barazandeh, M Vatankhah and MR Mohammadabadi. Genetics and non-genetics parameters of body weight for post-weaning traits in Raini Cashmere goats. Trop. Anim. Health Prod. 2013; 45, 1519-24.

[11] MR Nassiry, FE Shahroodi, J Mosafer, A Mohammadi, E Manshad, S Ghazanfari, MR Mohammad Abadi and GE Sulimova. Analysis and frequency of bovine lymphocyte antigen (BoLA-DRB3) alleles in Iranian Holstein cattle._Russ. J. Genet. 2005; 41, 664-8.

[12] A Norouzy, MR Nassiry, FE Shahrody, A Javadmanesh, MRM Abadi and GE Sulimova. Identification of bovine leucocyte adhesion deficiency (BLAD) carriers in Holstein and Brown Swiss AI bulls in Iran. Russ. J. Genet. 2005; 41, 1409-13.

[13] MN Ruzina, TA Shtyfurko, MR Mohammadabadi, OB Gendzhieva, T Tsedev and GE Sulimova. Polymorphism of the BoLA-DRB3 gene in the Mongolian, Kalmyk, and Yakut cattle breeds. Russ. J. Genet. 2010; 46, 456-63.

[14] Department of Livestock Development. Goat farming statistic in Thailand since 1998 to 2009 , Available at: http://www.dld.go.th/ict/stat_web/yearly/yearly 52, accessed January 2019. 
http://wjst.wu.ac.th

[15] S Miki. Effects of heat stress on bovine preimplantation embryos produced in vitro. Reprod. Dev. 2017; 63, 347-52.

[16] PL Senger. Review: Fertility factors in high producing dairy cows-which ones are really important. Prof. Anim. Sci. 2001; 17, 129-38.

[17] PF Surai. Vitamin E in avian reproduction. Poult. Avain. Biol. Rev. 1999; 10, 1-60.

[18] T Blanchard, J Ferguson, L Love, T Takeda, B Henderson, J Hasler and W Chalupa. Effect of dietary crude protein type. Am. J. Vet. Res. 1990; 51, 905-8.

[19] RD Smit and LE Chase. Nutrition and reproduction. Dairy Integrated Reproductive Management, 2010.

[20] R Funston. Nutrition and reproduction interaction. In: Proceedings of the Applied Reproductive Strategies in Beef Cattle. Billings, Montana, 2007, p. 149-62.

[21] LC Kappel and S Zidenberg. Manganese: Present Knowledge in nutrition. In: ML Brown (Ed.). International Life Sciences Institute Nutrition Foundation, Washington DC, 1999, p. 308.

[22] TG Dunn and GE Moss. Effects of nutrient deficiencies and excesses on reproductive efficiency of Livestock. J. Anim. Sci. 1992; 70, 1580-93.

[23] AOAC. Association of Official Analytical Chemists International (AOAC). Official Methods of Analysis. $17^{\text {th }}$ eds. AOAC International, Gaithersburg, 2000.

[24] ANMA Rahman, RB Abdullah and WE Wan-Khadijah. In vitro maturation of oocytes with special reference to goat: A review. Biotech. 2008; 7, 559-611.

[25] SG Haddad. Effect of dietary forage: Concentrate ratio on growth performance and carcass characteristic of growing Baladi kids. Small Rumin. Res. 2005; 57, 43-9.

[26] S Hwangbo, SH Choi, SH Kim, SW Son, DS Park, HS Lee and IH Jo. Effects of crude protein level in total mixed rations on growth performance and meat quality in growing Korean black goats. Asian Aust. J. Anim. Sci. 2009; 22, 1133-9.

[27] I Prieto, AL Goetsh, V Banskalieva, M Cameron, R Puchala, T Sahlu, LJ Dawson and SW Coleman. Effects of dietary protein concentration on postweaning growth of Boer crossbred and Spanish goat wethers. J. Anim. Sci. 2002; 78, 2275-81.

[28] T Negesse, M Rodehutscord and E Pfeffer. The effect of dietary crude protein level on intake growth protein retention and utilization of growing male Saanen kids. Small Rumin. Res. 2001; 39, 243-51.

[29] W Pralomkarn, S Saithanoo, S Kochapakdee and BW Norton. Effect of genotype and plane of nutrition on carcass characteristics of Thai native and Anglo-Nubian X Thai native male goats. Small Rumin. Res. 1995; 16, 21-5.

[30] K Intharak and J Saelim. Effect of crude protein concentration in total mixed rations on growth performance of Ango-Nubian crossbred goats. Annual Research Report 2008, Animal Nutrition Division, Department of Livestock Development, Ministry of Agriculture and Cooperative, p. 24670.

[31] F Kanyinji, H Kumagai, T Maeda, S Kaneshima and D Yokoi. Effects of supplementary inosine on nutrient digestibility ruminal fermentation and nitrogen balance in goats fed high amount of concentrate. Anim. Feed Sci. Tech. 2009; 152, 12-20.

[32] AK Pathak. Various factors affecting microbial protein synthesis in the rumen. Vet. World. 2008; 1, $186-9$.

[33] A Bach, S Calsamiglia and MD Stern. Nitrogen metabolism in the rumen. J. Dairy Sci. 2005; 88, 921.

[34] R Webb, B Nicholas, JG Gong, BK Campbell, CG Gutierrez, HA Garverick and DG Armstrong. Mechanisms regulating follicular development and selection of the dominant follicle. Reprod. Suppl. 2003; 61, 1-20.

[35] D Rondian, VJF Freitas, M Spinaci and G Galeati. Effect of nutrition on plasma progesterone levels metabolic parameters and small follicles development in unstimulated goats reared under constant photoperiod regimen. Reprod. Domest. Anim. 2005; 40, 548-52.

[36] JA Downing and RJ Scaramuzzi. Nutrient effects on ovulation rate ovarian function and the secretion of gonadotrophic and metabolic hormones in sheep. J. Reprod. Fertil. 1991; 43, 209-27. 
http://wjst.wu.ac.th

[37] R Funston. Nutrition and Reproduction Interaction, University of Nebraska, West Central Research and Extension Center, North Platte. In: Proceedings of the Applied Reproductive Strategies in Beef Cattle, Rapid City, South Dakota, 2006.

[38] RJV Saun. Effect of nutrition on reproduction in llamas and alpacas. Theriogenology 2008; 70, 50814.

[39] J Fahey, MP Boland and DO Callaghan. Effects of dietary urea on embryo development in super ovulated donor ewes and on embryo survival following transfer in recipient ewes. Proc. Annual Meet. British Soc. Animal Sci. 1998; 1998, 182.

[40] WR Butler. Review: Effect of protein nutrition on ovarian and uterine physiology in dairy cattle. $J$. Dairy Sci. 1999; 81, 2533-9. 